\title{
An integrative approach to identify sand fly vectors of leishmaniasis in Ethiopia by morphological and molecular techniques
}

\author{
Myrthe Pareyn ${ }^{1^{*}} \mathbb{D}$, Vit Dvorak ${ }^{2}$, Petr Halada ${ }^{3}$, Natalie Van Houtte ${ }^{1}$, Nigatu Girma ${ }^{4}$, Wim de Kesel ${ }^{1}$, \\ Behailu Merdekios ${ }^{5}$, Fekadu Massebo ${ }^{4}$, Herwig Leirs ${ }^{1}$ and Petr Volf ${ }^{2^{*}}$
}

\begin{abstract}
Background: Ethiopia is affected by human leishmaniasis caused by several Leishmania species and transmitted by a variety of sand fly vectors of the genus Phlebotomus. The sand fly fauna in Ethiopia is highly diverse and some species are closely related and similar in morphology, resulting in difficulties with species identification that requires deployment of molecular techniques. DNA barcoding entails high costs, requires time and lacks reference sequences for many Ethiopian species. Yet, proper species identification is pivotal for epidemiological surveillance as species differ in their actual involvement in transmission cycles. Recently, protein profiling using MALDI-TOF mass spectrometry has been introduced as a promising technique for sand fly identification.
\end{abstract}

Methods: In our study, we used an integrative taxonomic approach to identify most of the important sand fly vectors of leishmaniasis in Ethiopia, applying three complementary methods: morphological assessment, sequencing analysis of two genetic markers, and MALDI-TOF MS protein profiling.

Results: Although morphological assessment resulted in some inconclusive identifications, both DNA- and proteinbased techniques performed well, providing a similar hierarchical clustering pattern for the analyzed species. Both methods generated species-specific sequences or protein patterns for all species except for Phlebotomus pedifer and P. longipes, the two presumed vectors of Leishmania aethiopica, suggesting that they may represent a single species, $P$. longipes Parrot \& Martin. All three approaches also revealed that the collected specimens of Adlerius sp. differ from $P$. (Adlerius) arabicus, the only species of Adlerius currently reported in Ethiopia, and molecular comparisons indicate that it may represent a yet undescribed new species.

Conclusions: Our study uses three complementary taxonomical methods for species identification of taxonomically challenging and yet medically import Ethiopian sand flies. The generated MALDI-TOF MS protein profiles resulted in unambiguous identifications, hence showing suitability of this technique for sand fly species identification. Furthermore, our results contribute to the still inadequate knowledge of the sand fly fauna of Ethiopia, a country severely burdened with human leishmaniasis.

Keywords: Sand flies, Phlebotomus, Morphology, DNA barcoding, MALDI-TOF mass spectrometry, Protein profiling, Ethiopia

\footnotetext{
*Correspondence: myrthe.pareyn@uantwerpen.be; volf@cesnet.cz

${ }^{1}$ Evolutionary Ecology Group, Biology Department, University

of Antwerp, Antwerp, Belgium

2 Department of Parasitology, Faculty of Science, Charles University,

Prague, Czech Republic

Full list of author information is available at the end of the article
}

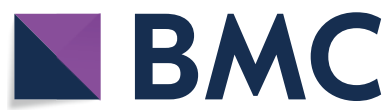

c The Author(s) 2020. This article is licensed under a Creative Commons Attribution 4.0 International License, which permits use, sharing, adaptation, distribution and reproduction in any medium or format, as long as you give appropriate credit to the original author(s) and the source, provide a link to the Creative Commons licence, and indicate if changes were made. The images or other third party material in this article are included in the article's Creative Commons licence, unless indicated otherwise in a credit line to the material. If material is not included in the article's Creative Commons licence and your intended use is not permitted by statutory regulation or exceeds the permitted use, you will need to obtain permission directly from the copyright holder. To view a copy of this licence, visit http://creativeco mmons.org/licenses/by/4.0/. The Creative Commons Public Domain Dedication waiver (http://creativecommons.org/publicdomain/ zero/1.0/) applies to the data made available in this article, unless otherwise stated in a credit line to the data. 


\section{Background}

Phlebotomine sand flies (Diptera, Phlebotominae) are hematophagous insects of great medical importance as the females of some species are the vectors of the protozoans Leishmania spp., which are transmitted during blood-feeding on a vertebrate host. Human leishmaniasis manifests in three major clinical forms: visceral $(\mathrm{VL})$, cutaneous $(\mathrm{CL})$, and mucocutaneous (MCL) leishmaniasis [1, 2].

All three forms affect people in Ethiopia, particularly the poorest part of the population living in rural areas [3, 4]. VL is generally endemic in the lowlands widespread in the country and is caused by Leishmania donovani. Proven vectors of VL in different regions in Ethiopia are Phlebotomus orientalis, P. martini and to a lesser extent $P$. celiae [5-9]. Localized and diffuse forms of $\mathrm{CL}$, and MCL occur mainly at mid-highland altitudes, on the mountain ridges of the Ethiopian Rift Valley. The main causative parasite species is L. aethiopica, which is transmitted by $P$. longipes in northern and central Ethiopia and $P$. pedifer in southwestern Ethiopia [10-16].

It is pivotal for entomological and eco-epidemiological research to accurately identify the sand fly species that act as vectors in a particular area and assess their ecology and behavior, as this information is a prerequisite for implementation of efficient, targeted control programmes [17].

Morphological identification is performed by examination of the mounted head and abdomen of the sand flies which bear the main distinctive characteristics for classification (cibarial and pharengeal armature, genitalia). However, this taxonomic approach is labor-intensive, demands high proficiency, and morphological keys are often obsolete and incomprehensive, leading to incorrect identifications [18-20].

To overcome these drawbacks, studies are frequently shifting to molecular techniques, mostly DNA sequencing analyses which allow simultaneous processing of samples, provide reliable identifications and have good reference sequences available for many species. Yet, this approach is technically demanding, considered costly for large-scale studies and its validity depends on the genetic variability of the target locus $[21,22]$.

Recently, an alternative molecular method, protein profiling by matrix-assisted laser desorption/ionization time-of-flight mass spectrometry (MALDI-TOF MS), has been introduced for species identification in different arthropod families, including sand flies [20, 23-28]. This approach provides unique protein profiles that allow unambiguous species identification and sample processing is rapid, simple and cost-effective. However, it still needs validation on field specimens and requires a centralized database to approve its use for routine species identification of sand flies [20,29]. As the method utilizes only certain body parts, in sand flies particularly the thorax in standardized protocols [20], a coordinated sample preparation allows simultaneous or later application of other techniques, including morphological analysis of the mounted head and genitalia and DNA-based techniques using template DNA isolated from the sand fly abdomen.

The sand fly fauna in Ethiopia is very diverse, comprising remarkable numbers of species in both genera Sergentomyia and Phlebotomus, within which species of at least six subgenera were recorded, many of them proven or suspected vectors of several Leishmania species and thus of great medical significance. Among these, some closely related sand fly species are remarkably similar in morphological characteristics, resulting in many difficulties for conclusive species identification [30-33]. Especially females of some species are challenging to distinguish from each other as species-specific morphological features are poorly described or undefined. These species, however, often do not play the same role in Leishmania transmission which is hindering sand fly ecology studies and implementation of control measures accordingly, indicating that more sophisticated techniques are necessary for species differentiation [30,31]. DNA barcoding could be an appropriate alternative, although very few reference sequences of the Ethiopian sand fly species are currently available in genetic databases and analyses are rather too costly to process large sample sizes.

Our study presents for the first time an integrative taxonomic approach to identify most of the important sand fly vectors of leishmaniasis in Ethiopia, applying three complementary methods: morphological assessment, sequencing analysis of two genetic markers, and MALDI-TOF MS protein profiling. We aimed to demonstrate that MALDI-TOF MS protein profiling could be a suitable taxonomical technique, providing unambiguous sand fly species identification in Ethiopia. Furthermore, our results contribute to the currently still inadequate knowledge of the sand fly fauna in Ethiopia, a region among those most affected by the burden of human leishmaniasis.

\section{Methods \\ Sand flies}

Field specimens were captured in May and September 2019 from different CL (Hagere Selam in the north, Saris in the center and Ochollo in the southwest) and VL (Aba Roba, Dimeka and Turmi in the south) foci in Ethiopia (Fig. 1). Sand flies were captured with CDC miniature light traps (John W. Hock Company, Gainesville, Florida, USA), which were set at 18:00 $\mathrm{h}$ and collected at 7:00 $\mathrm{h}$ the next morning. In order to capture $\mathrm{CL}$ vectors in the 
mid-highlands, traps were placed in caves or around rocky areas, whereas to capture VL vectors in the lowlands, traps were set nearby termite hills and human dwellings [11, 34, 35]. Collected sand flies were preserved in $70 \%$ ethanol and stored at $-20{ }^{\circ} \mathrm{C}[36]$.

\section{Morphological identification of sand fly species}

The head and terminal segments of the abdomen of the sand fly specimens were mounted using CMCP-10 high viscosity mounting medium (Polysciences, Hirschberg, Germany) and species identification was done according to relevant morphological keys [30-32, 37-42]. Slidemounted specimens were observed using a light microscope Olympus BX51 (Olympus Life Science, Waltham, USA) with a camera system Olympus D70. Morphological characters were measured using the QuickPHOTO MICRO 3.0 software (Promicra, Prague, Czech Republic).

\section{Molecular identification of sand fly species}

After mounting, the remaining part of the abdomen was used for molecular identification of the sand fly species. DNA was isolated using the QIAamp DNA Mini Kit (Qiagen, Hilden, Germany). Samples were subsequently subjected to two PCRs targeting (i) a fragment of the cytochrome $c$ oxidase subunit 1 ( $\operatorname{cox} 1$ ) with primers LCO 1490 (5'-GGT CAA ATC ATA AAG ATA TTG G-3') and HCO 2198 (5'-TAA ACT TCA GGG TGA CCA AAA AAT CA-3') in a total reaction volume of 25 $\mu \mathrm{l}$ as described by Folmer et al. [43]; and (ii) the nad4 gene with primers ND4ar (5'-AAR GCT CAT GTT GAA GC-3') and ND4c (5'-ATT TAA AGG YAA TCA ATG TAA- $3^{\prime}$ ) in a reaction volume of $50 \mu$ l based on Soto et al. [44]. Amplicons were visualized on a $1 \%$ agarose gel and obtained products were purified with the QIAquick PCR Purification Kit (Qiagen). These were sent to Vlaams Instituut voor Biotechnologie (VIB; University of Antwerp, Wilrijk, Belgium) or BIOCEV OMICS genetika (Charles University, Vestec, Czech Republic) for Sanger sequencing in two directions with the primers used for DNA amplification.

\section{Phylogenetic analyses}

The obtained chromatograms were edited and consensus sequences were generated for each specimen, which were compared with reference sequences in GenBank using BLAST. Multiple sequence alignment of the $\operatorname{cox} 1$ and nad4 sequences was performed using the Clustal W tool implemented in MEGA X 10.1 and primers were trimmed to have sequences with an equal length of 658 bp and $597 \mathrm{bp}$, respectively [45, 46]. The nucleotide composition and sequence divergence were calculated with the Kimura 2-parameter model (K2P) and a distance matrix was generated $[47,48]$. A neighbor-joining (NJ) tree of the K2P distances was created using a bootstrapping method with 1000 replicates for a graphical presentation of the clustering pattern of the sand fly species $[46,49]$. To generate a NJ tree for our specimens of the subgenus Adlerius in combination with other species of the same subgenus, cox 1 sequences were retrieved from GenBank. Based on the NJ trees, groups of species were indicated to assess the inter- and intra-species distances.

\section{MALDI-TOF MS analysis of sand fly species}

The MALDI matrix was prepared fresh as an aqueous $60 \%$ acetonitrile $/ 0.3 \%$ TFA solution of sinapinic acid (30 $\mathrm{mg} / \mathrm{ml}$; Bruker Daltonics, Bremen, Germany). Specimens stored in $70 \%$ ethanol were air-dried, dissected and thoraces were manually ground in $10 \mu \mathrm{l}$ of $25 \%$ formic acid by a BioVortexer homogenizer (BioSpec, Bartlesville, USA) with sterile disposable pestles. After a short centrifugation of the homogenate $(10,000 \times g$ for $15 \mathrm{~s}), 2$ $\mu \mathrm{l}$ was mixed with $2 \mu \mathrm{l}$ of MALDI matrix and $1 \mu \mathrm{l}$ was deposited and air-dried on a steel target plate (Bruker Daltonics) in duplicate. Protein mass spectra were measured in a mass range of $4-25 \mathrm{kDa}$ by an Autoflex Speed MALDI-TOF spectrometer (Bruker Daltonics) and calibrated externally with the Bruker Protein Calibration Standard I. Each spectrum was acquired as a sum of 4000 manually adjusted laser shots $(20 \times 200$ shots from different positions of the target spot) and visualized by FlexAnalysis 3.4 software (Bruker Daltronics).

For cluster analysis, the protein profiles were processed (normalization, smoothing, baseline subtraction and peak picking) using MALDI Biotyper 3.1. (Bruker Daltronics). The peak picking parameters for generation of a main spectrum (MSP) were to include maximum 100 peaks, which had a signal-to-noise ratio greater than 3 and a relative intensity of minimum $1 \%$ of the most intense peak. The desired peak frequency for MSP reference spectra was set to $60 \%$. For MSP dendrogram creation, a correlation distance measure and average linkage parameters were applied. The dendrograms were generated using the individual MSPs or MSP references created for each sand fly species. In addition to six fieldcaught Ethiopian species, MSP references from our sand fly database were included (country of origin is given in parentheses): P. ariasi (France); P. kandelakii (Georgia); P. longicuspis (Morocco); P. neglectus (Croatia); P. orientalis (Ethiopia); P. perfiliewi (Macedonia); P. perniciosus (Spain); P. tobbi (Northern Macedonia); P. arabicus (Israel); P. balcanicus (Georgia); P. creticus (Crete); P. halepensis (Georgia); P. simici (Macedonia). Phlebotomus arabicus and $P$. orientalis originated from colonies maintained in Prague, the others were field-collected. 


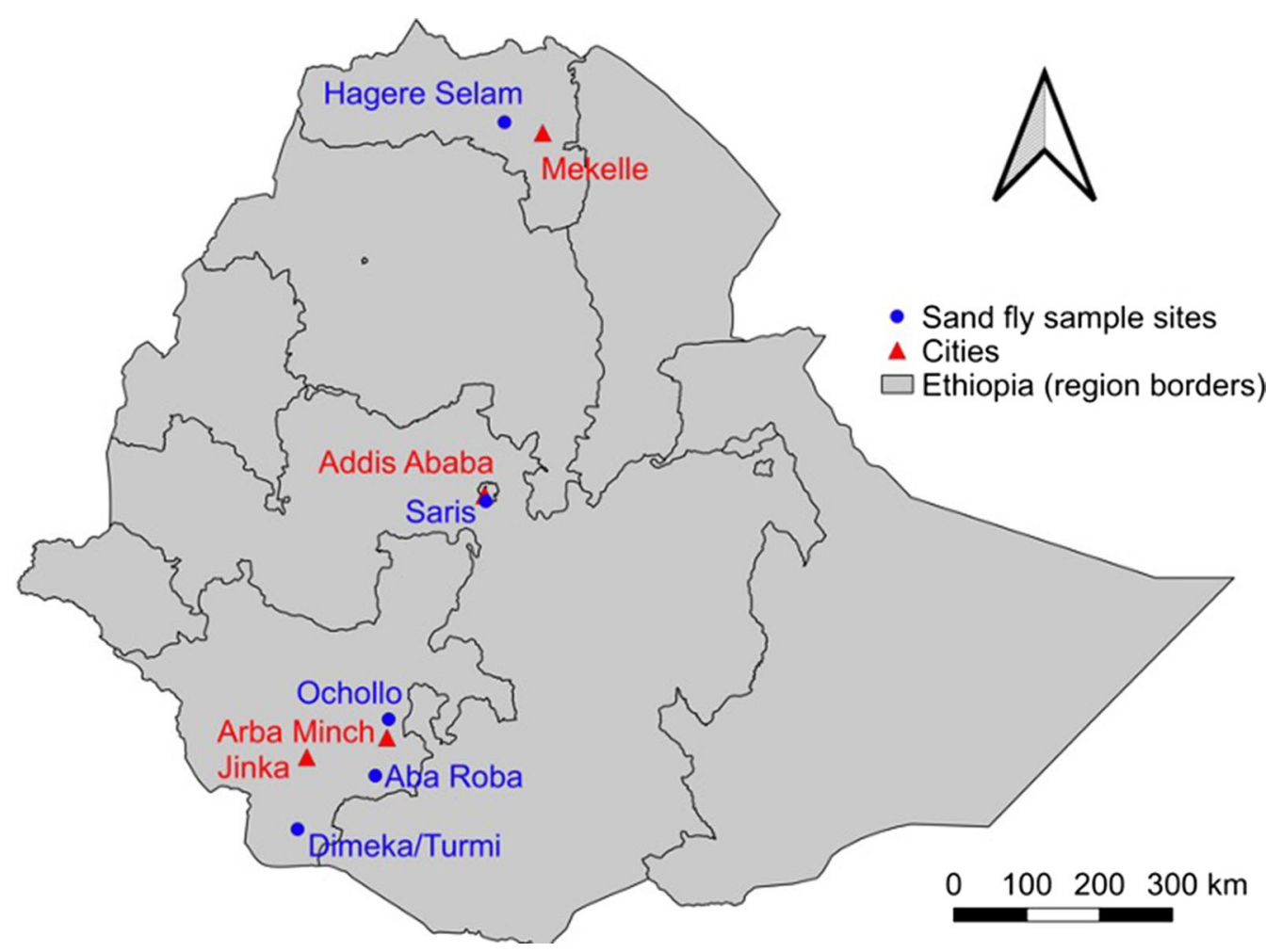

Fig. 1 Sampling locations of field collected sand flies $[66,67]$. Blue dots represent the places where field collected sand flies came from. CL foci: Hagere Selam (Tigray Region); Saris (Addis Ababa city administration); and Ochollo (Southern Nations, Nationalities and Peoples'Region, SNNPR). VL foci: Aba Roba, Dimeka and Turmi (SNNPR). The cities nearby the sample sites are displayed by red triangles

\section{Results}

\section{Morphological species identification}

Morphological analysis identified six sand fly species of four subgenera. Three species, P. (Phlebotomus) duboscqi, P. (Synphlebotomus) celiae and P. (Sy.) martini, were identified in VL endemic sites in the south (Dimeka, Turmi and Aba Roba). Phlebotomus (Larroussius) pedifer was collected in Ochollo and P. (La.) longipes in Saris and Hagere Selam. A main feature to differentiate the two species of the subgenus Larroussius is based on the bending of the tip of the male aedeagus [31, 41]. However, our specimens showed a varying range of tip endings within a single species (Fig. 2) that did not allow clear differentiation between the species-specific morphological arrangements of the two species. Furthermore, we counted overlapping numbers of inner surface coxite hairs, being 39 (31-48, $n=43)$ for $P$. pedifer from Ochollo, 31 (29-36, $n=13)$ for $P$. longipes from Hagere Selam and 44 (40-48, $n=2)$ for $P$. longipes from Saris. Therefore, species identification of the two Larroussius species was mainly based on previous geographical presence records $[10,11,34]$.

Females of the species within the subgenera Synphlebotomus and Larroussius could often not be separated to species level based on morphological features [30, 41, 50, 51].

Seven males and one female of an additional species were captured from a single cave nearby Hagere Selam $\left(13^{\circ} 40^{\prime} 14^{\prime \prime} \mathrm{N}, 39^{\circ} 07^{\prime} 29^{\prime \prime} \mathrm{E}\right)$ and identified as a species of the subgenus Adlerius (further referred to as 'Adlerius sp.'). Morphometric analysis of four male specimens of Adlerius sp. (Table 1) indicates that our sand flies show high similarity in the number and position of coxite hairs and the aedeagus tip to tooth distance as described for $P$. davidi [37]. The style, coxite and aedeagus length of our specimens, however, are longer than reported for $P$. davidi, but shorter than measured and described for $P$. arabicus and fit more to $P$. naqbenius. Accordingly, no conclusive species identification could be reached for Adlerius sp.

\section{Sand fly species identification by molecular techniques}

Most specimens tested gave reproducible MALDITOF MS spectra with a high number of intense signals (Fig. 3a). Except for the protein profiles of $P$. pedifer and $P$. longipes, each species generated a heterogeneous spectrum with species-specific peaks allowing 
unambiguous species identification. The dendrogram of the specimen's protein profiles (Fig. $3 \mathrm{~b}$ ) indicates that all subgenera cluster on distinct branches. The closely related $P$. martini and $P$. celiae were clearly distinguished from each other, whereas the specimens of the subgenus Larroussius from all three sites grouped in a single cluster. The Adlerius sp. formed its own separate branch.

Taxonomic clustering of the cox 1 and nad4 sequences in the NJ tree (Fig. 4a, b, respectively) substantiates the hierarchical clustering of the protein profiles (Fig. 3b), separating all species except for the two Larroussius species. The mean intra-group K2P distances within the $P$. longipes and $P$. pedifer cluster was only 0.3\% (SD 0.1) for cox 1 and $0.1 \%$ (SD 0.1) for nad4 genes (Additional file 1: Table S1), indicating that there is no genetic difference between the two presumable species. The K2P distance between $P$. martini and $P$. celiae was only $1.6 \%$ (SD 0.4) for $\operatorname{cox} 1$ and $1.2 \%$ (SD 0.3 ) for nad4 genes, yet the species clearly clustered in distinct clades (Additional file 2 : Table S2).

The dendrogram including the MSP reference spectra of $P$. pedifer, $P$. longipes, Adlerius sp. and other available species of the subgenera Larroussius and Adlerius from our library (Fig. 5) demonstrates that only the two
Ethiopian CL vectors cannot be distinguished from each other, while the protein profiling could clearly differentiate all other analyzed species, including the closely related $P$. tobbi and $P$. perfiliewi that provide highly similar, yet species-specific protein spectra. The dendrogram depicts that Adlerius sp. is closely related with $P$. arabicus from Israel but some distinct peaks were found in their protein profiles (Additional file 3: Figure S1). Moreover, there is a large relative distance between the MSP reference spectra of the two species (Fig. 5), demonstrating that Adlerius sp. is definitely not $P$. arabicus.

Furthermore, the cox 1 sequence profile of the Adlerius sp. was compared with available GenBank sequences of other species of the Adlerius subgenus (Fig. 6), which supports the MSP dendrogram (Fig. 5), indicating that the species is closely related to $P$. arabicus but constitutes a distinct branch with a K2P distance of $6.5 \%$ (SD 1.2, Additional file 4: Table S3).

\section{Discussion}

Since East Africa accounts worldwide among the regions most affected by both cutaneous and visceral leishmaniasis, phlebotomine sand flies occurring in the Horn of Africa have been extensively studied due to their exclusive

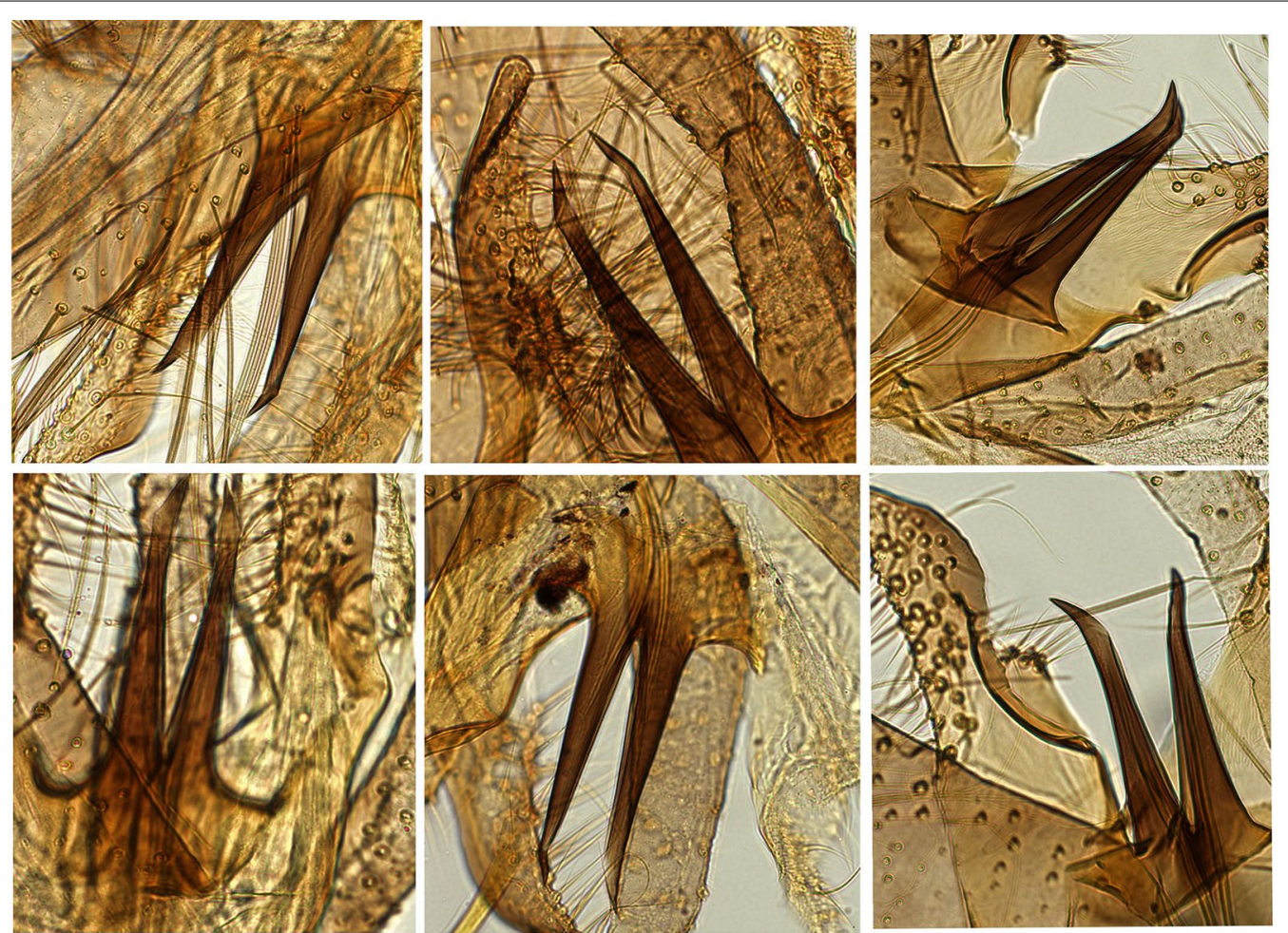

Fig. 2 Aedeagi of male Phlebotomus longipes (left two columns 1 and 2) and P. pedifer (right column 3). Phlebotomus longipes was acquired for Hagere Selam and Saris (northern and central Ethiopia) and P. pedifer from Ochollo (southern Ethiopia) 
Table 1 Morphometric analysis of the Adlerius sp. from Ethiopia, in comparison with other Adlerius species

\begin{tabular}{|c|c|c|c|c|c|c|c|}
\hline $\begin{array}{l}\text { Species (country, } \\
\text { reference) }\end{array}$ & Ascoid formula & Style length & Coxite length & No. of coxite hairs & $\begin{array}{l}\text { Position coxite } \\
\text { hairs }\end{array}$ & Aedeagus length & $\begin{array}{l}\text { Aedeagus tip to } \\
\text { tooth }\end{array}$ \\
\hline $\begin{array}{l}\text { Adlerius sp. }{ }^{a} \text { (Ethio- } \\
\text { pia, Pareyn) }\end{array}$ & $2 / 3-7,1 / 8-15$ & $173(158-188)$ & $366(355-387)$ & $45(36-52)$ & $0.56(0.51-0.57)$ & $186(181-195)$ & $13(11-15)$ \\
\hline $\begin{array}{l}\text { P. davidi (Yemen \& } \\
\text { Ethiopia, Arte- } \\
\text { miev [37]) }\end{array}$ & $2 / 3-7,1 / 8-15$ & $157(156-160)$ & $315(300-328)$ & $46(38-59)$ & $0.59(0.55-0.64)$ & $162(152-172)$ & $12(10-14)$ \\
\hline $\begin{array}{l}\text { P. arabicus (Israel, } \\
\text { PV, unpublished) }\end{array}$ & $2 / 3-7$ & $189(176-206)$ & $386(370-428)$ & $64(55-76)$ & - & $183(176-206)$ & $20(17-25)$ \\
\hline $\begin{array}{l}\text { P. arabicus TYPE } \\
\text { (Saudi Arabia, } \\
\text { Lewis \& Büttiker } \\
\text { [64]) }\end{array}$ & $2 / 7(8)$ & 190 & 360 & 57 & 0.59 & 190 & - \\
\hline $\begin{array}{l}\text { P. arabicus HESUA } \\
\text { (Saudi Arabia, } \\
\text { Lewis \& Büttiker } \\
\text { [64]) }\end{array}$ & $2 / 7(8)$ & - & - & $54(42-69)$ & $(0.50-0.59)$ & - & $(12-22)$ \\
\hline $\begin{array}{l}\text { "P. Naqben" species } \\
\text { (Saudi Arabia, } \\
\text { Lewis \& Büttiker } \\
1[64] \text { ) }\end{array}$ & $2 / 7$ & - & - & $54-98$ & 0.58 & - & $(15-22)$ \\
\hline $\begin{array}{l}\text { P. naqbenius (Saudi } \\
\text { Arabia, Lewis \& } \\
\text { Büttiker, [65]) }\end{array}$ & & & & $53(41-69)$ & & & \\
\hline $\begin{array}{l}\text { P. naqbenius } \\
\text { holotype (PV, } \\
\text { unpublished) }\end{array}$ & $2 / 7$ & 185 & 357 & 60 & - & 172 & 16 \\
\hline $\begin{array}{l}\text { P. naqbenius } \\
\text { syntype (PV, } \\
\text { unpublished) }\end{array}$ & $2 / 7$ & 196 & 381 & 80 & 0.6 & 185 & 21 \\
\hline
\end{tabular}

Notes: Measurements were collected from: ${ }^{a}$ four males from Ethiopia; the holotype and syntype of $P$. naqbenius were loaned from The National History Museum, London, UK; ${ }^{b}$ examination of the type-series; ${ }^{c}$ examination of own samples from Hesua; ${ }^{d}$ We speculate that the authors attributed the numbers of the coxite hairs incorrectly; All measurements are in $\mu \mathrm{m}$

role as vectors in the transmission cycles. Unfortunately, whereas considerable amount of knowledge regarding the diverse sand fly fauna of Ethiopia has been gradually gathered, the last comprehensive morphological key for species identification has not been updated for more than five decades [42], leaving the attempt to identify the specimens collected in field surveys very tedious and challenging. This further urges the need to deploy alternative molecular techniques that have recently emerged and were successfully adopted for species identification of various medically significant arthropods. In this study, we applied an integrative taxonomic approach to identify most $\mathrm{CL}$ and VL vectors in Ethiopia using a combination of morphological assessment, sequencing analysis of two genetic markers and MALDI-TOF MS protein profiling, and demonstrate some novelties in the complex sand fly fauna of Ethiopia.

The three vectors of $L$. donovani in Ethiopia are P. orientalis, $P$. martini and $P$. celiae. The former is a species of the subgenus Larroussius, whereas the latter two belong to the subgenus Synphlebotomus and occur sympatrically in Aba Roba focus in southwestern Ethiopia [32, 35].
While to our knowledge this is the only place where $P$. celiae has been identified in Ethiopia, $P$. martini is more widespread, serving as a vector also in the northwestern and southeastern parts of the country, where it sometimes cohabitates with $P$. orientalis $[8,52,53]$.

Males of $P$. martini and $P$. celiae can be easily distinguished based on the morphology of the lateral lobes on their external genitalia, but females of these two species were previously regarded as indistinguishable until Gebre-Michael \& Lane [32] differentiated them based on the labrum length and labrum-to-wing length ratio. Moreover, the spermathecal ducts vary in length, but this characteristic cannot be used for routine identifications, as it requires dissecting out the fragile ducts. However, still a few field-caught specimens in the study of GebreMichael \& Lane [32] could not surely be identified by these characters and the measurement ranges do not match with findings from Davidson et al. [54] in Egypt and the original description of $P$. martini by Parrot et al. [55] in Dire Dawa (about $600 \mathrm{~km}$ from Aba Roba in eastern Ethiopia). This could be due to the geographical distance or environmental conditions but as a result these 


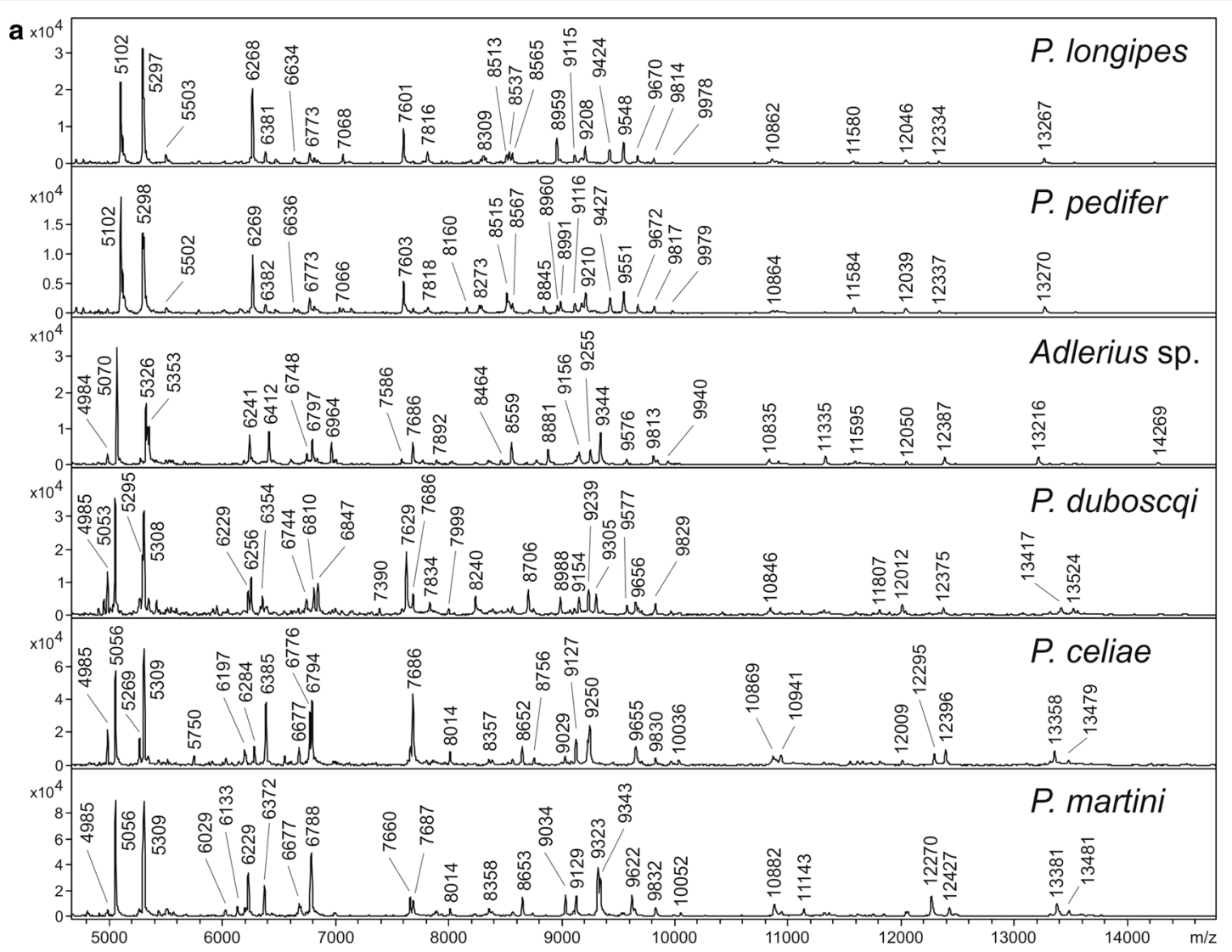

b

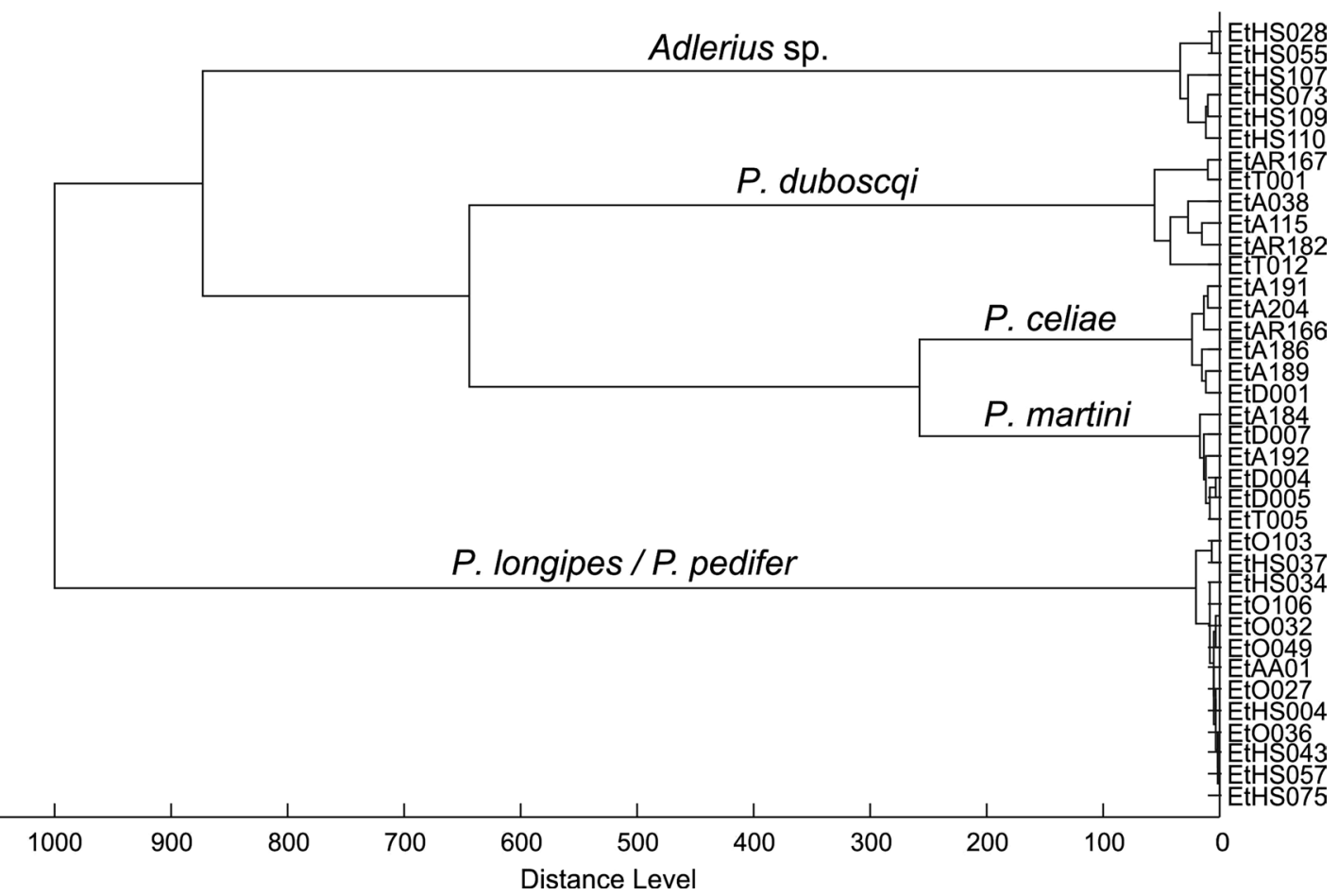

Fig. 3 MALDI-TOF mass spectra (a) and the corresponding dendrogram of the protein profiles (b) of Ethiopian sand fly species. Zoomed mass range of 4 to $15 \mathrm{kDa}$ is shown in $\mathbf{a}$ and distances in $\mathbf{b}$ are displayed in relative units 


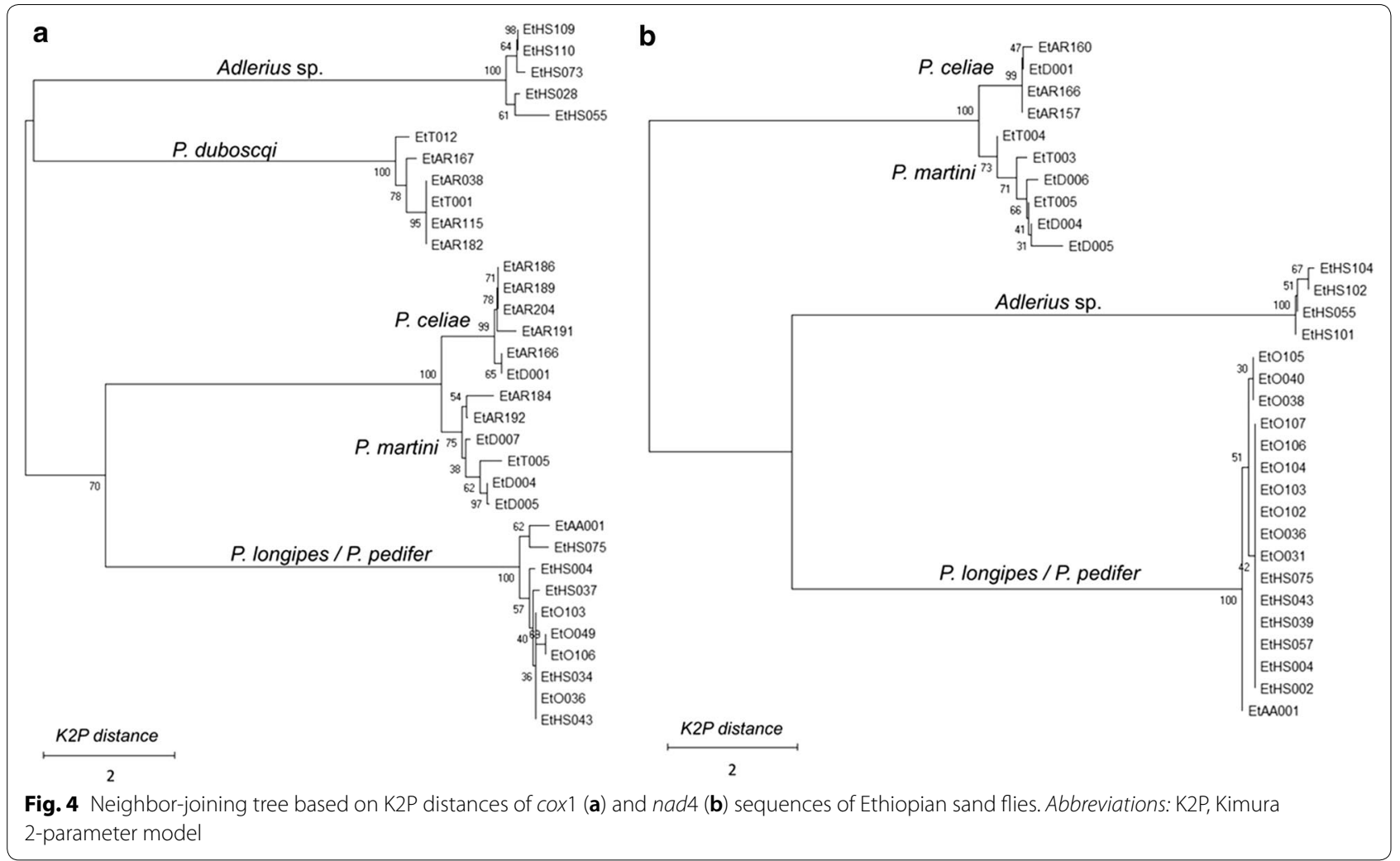

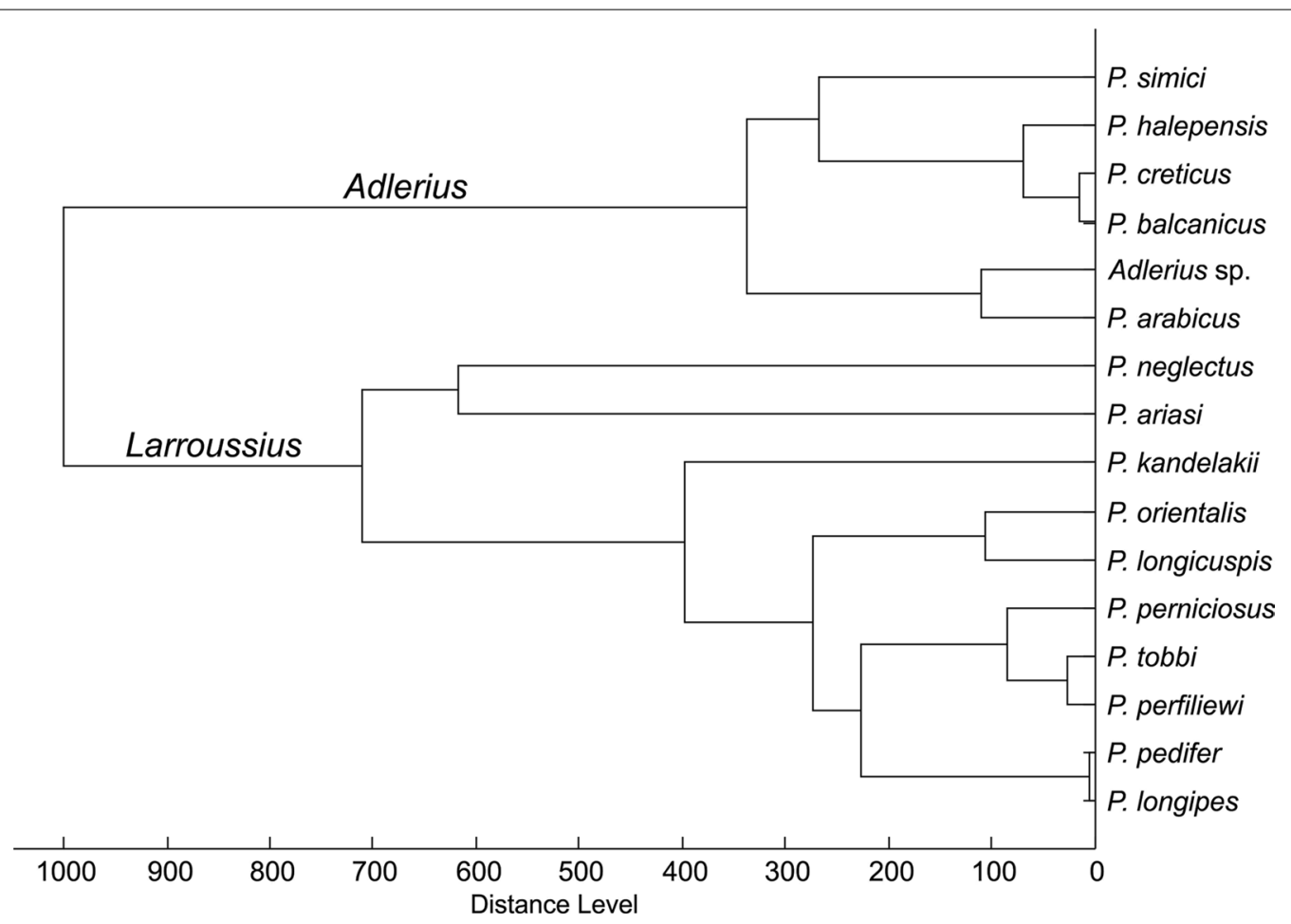

Fig. 5 Dendrogram of MSP reference spectra of Larroussius and Adlerius sand flies from Ethiopia and our library. The origin of the species is given in the methods section. Specifically, P. arabicus was derived from the sand fly facility at Charles University, Czech Republic, which originated from northern Israel. Distances are displayed in relative units. Abbreviations: MSP, main spectrum 


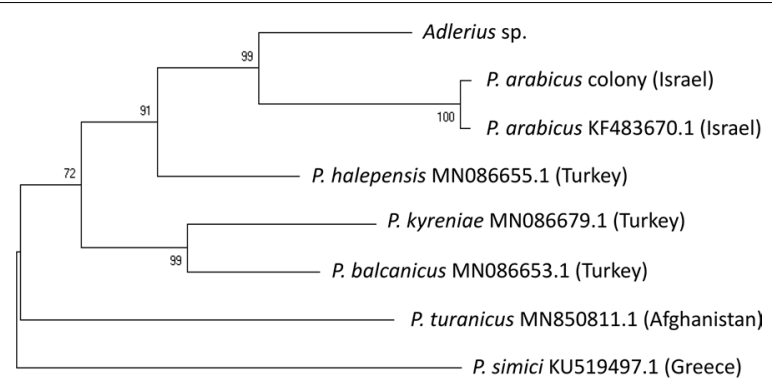

$\underset{2}{\text { K2P distance }}$

Fig. 6 Neighbor-joining tree of the cox 1 gene of Adlerius sp. from Ethiopia and other Adlerius species. Accession codes of the species retrieved from GenBank are displayed after the species name. The $P$. arabicus colony was obtained from Israel. Abbreviations: K2P, Kimura 2-parameter model

measurements can presumably not be extrapolated to a larger area without leading to misidentifications.

Phlebotomus martini and P. celiae have a different distribution, infection prevalence and abundance, and thus their contribution to disease transmission varies [35]. Therefore, proper species identification is pivotal and requires novel determination techniques. Both genetic and MALDI-TOF MS analyses in this study pointed out that DNA marker sequences and protein profiles were similar, and enable rapid and conclusive species identification, indicating that this is a suitable approach for species identification.

Sand flies were also captured from different CL endemic sites in Ethiopia, where we found two species of the subgenus Larroussius, identified morphologically as $P$. pedifer and $P$. longipes. The latter species was first described by Parrot et al. [56] in 1939 in Ethiopia, but the species complex was re-examined by Lewis et al. [41] in 1972, who compared presumed P. longipes specimens from Kenya and South Sudan with $P$. longipes from different places in northern, western and central Ethiopia. The species from Kenya appeared smaller than the ones from Ethiopia, although this was probably a geographical difference. Moreover, the authors describe that male specimens from Kenya had an up-turned foot-like aedeagus, whereas it was only slightly up-turned in the Ethiopian species. Therefore, the Kenyan specimens were described as a new related species, $P$. pedifer, which was later also found as the CL vector in southwestern Ethiopia (Ochollo) [41]. Killick-Kendrick et al. [31] later confirmed that males of $P$. pedifer and $P$. longipes can be distinguished based on this slight difference in the aedeagus shape and additionally also the number of inner surface coxite hairs, being 50-60 for $P$. pedifer and 35-50 for $P$. longipes. In contrast, females of the two species are considered indistinguishable [30, 41], except for a slight difference in the base of the spermathecal ducts, which often still results in inconclusive identifications [31].

Results of the present study show that the tips of the aedeagi of the Ethiopian CL vectors varied among all collected specimens, being partially dependent on the orientation of the specimen on the slide. Also, the number of coxite hairs overlapped significantly between $P$. pedifer and $P$. longipes and seems more geographically dependent than species-specific. Accordingly, we conclude that these morphological characters are not appropriate for species identification. Moreover, sequences of two genetic markers and protein profiles of $P$. pedifer and $P$. longipes were found identical, whereas all other species of the subgenus Larroussius in our database could be easily distinguished using MALDI-TOF MS. This includes also $P$. orientalis protein profiles generated by colony specimens originating from an Ethiopian VL endemic site, Melka Werer. Even though $P$. orientalis is morphologically closely related to $P$. pedifer and $P$. longipes [51], our results show that this species can easily be distinguished based on MALDI-TOF MS protein profiling. Among other analyzed Larroussius species, the method also clearly differentiated between $P$. perfiliewi and $P$. tobbi which are very similar morphologically and have a similar geographical distribution [57-59], demonstrating the discriminatory power of the approach. Furthermore, the ecology of $P$. pedifer and P. longipes is comparable, as both occur in close association with hyraxes, inhabiting caves, basalt cliffs, cracks in boulders and gorges at midhighland altitudes [10, 11, 34]. Collectively, our results suggest that the two species incriminated in the transmission cycle of $L$. aethiopica may actually represent a single species, $P$. longipes, which was described first.

Phlebotomus duboscqi was found in the Aba Roba focus and could easily be identified by MALDI-TOF MS as it matched with $P$. duboscqi from Senegal in our reference database. Two other species of the subgenus Phlebotomus were recorded elsewhere in Ethiopia, namely $P$. papatasi and $P$. bergeroti, which are sympatric with $P$. duboscqi in some areas $[60,61]$. In these locations, taxonomic tools like MALDI-TOF MS protein profiling can be very useful for entomological studies to differentiate similar species and to thoroughly investigate their potential roles in Leishmania transmission.

Another Phlebotomus species was found in Hagere Selam, which belonged to the subgenus Adlerius according to the morphology of the collected specimens. The only other currently reported Adlerius species in Ethiopia is $P$. arabicus, which has been described in the upper Awash Valley, where it was captured from rocky valleys and found infected with Leishmania parasites, although the species could not be identified due to contamination 
[62]. In Israel, $P$. arabicus is known as an efficient vector of $L$. tropica in rocky places colonized by hyraxes [63]. Our specimens were also captured in caves together with $P$. longipes. Morphometric and molecular analyses in our study, however, show that the captured species is definitely not $P$. arabicus.

In 1980, Artemiev [37] described four males and one female sand fly from Yemen and one male and one female sand fly from Ethiopia as $P$. davidi. The Ethiopian specimens were derived from the area around Langano Lake, approximately $200 \mathrm{~km}$ south of Addis Ababa. Our measurements of several morphological parameters, namely number of coxite hairs and the distance from the aedeagus tip to tooth, fit best with the description of $P$. davidi [37]. However, the coxite, style and aedeagus length were slightly larger than described by Artemiev [37], which can be due to small sample sizes and geographical variation. Moreover, this author described that the antennae of the male specimen from Ethiopia were missing and that the female specimen from Ethiopia had a different pharynx than the one from Yemen, requiring more specimens from both countries to determine the true taxonomy [37]. This suggests that the species from Ethiopia was potentially different from the holotype of $P$. davidi collected in Yemen.

Lewis \& Büttiker [64] questioned the validity of $P$. davidi as a species based on doubts about the value of the ascoid formula that also distinguished it from $P$. arabicus. While not addressing apparently different numbers of coxite hairs and emphasizing the overlapping values of wing lengths and possible same or varying ascoid formulae, they concluded that specimens from Ethiopia previously identified as $P$. davidi are a geographical variant of $P$. arabicus and regarded $P$. davidi as its synonym. Interestingly, in the same study, the authors collected specimens of another Adlerius species in several localities in Saudi Arabia, provisionally named "P. Naqben", with a remarkably wide range in number of coxite hairs (54-98) [64]. In a later study, Lewis \& Büttiker [65] formally described it as $P$. naqbenius. However, for this new species they do not provide the morphological characters regarded as important for the subgenus Adlerius by Artemiev [37] (ascoid formula, length of style, coxite and aedeagus tip to tooth) and they base its description on the number of coxite hairs, which they nevertheless now find significantly lower compared to P. arabicus. The authors did not discuss further this abrupt change in their understanding of $P$. arabicus and $P$. naqbenius morphology and we speculate that the authors attributed the number of coxite hairs incorrectly. It should be noted that while the validity of $P$. naqbenius was later never formally challenged, there are no recent records of this species in faunistic surveys from Saudi Arabia in the last decades and no molecular reference data are available. We hypothesize that, based on the scarce morphological data, our specimens of Adlerius sp. do not represent an Ethiopian population of $P$. naqbenius. On the contrary, they are morphologically more similar to the Ethiopian specimens described as P. davidi by Artemiev [37] and together they represent a different species from specimens collected in Yemen. This suggests that investigation on its taxonomy, distribution and potential role in Leishmania transmission is required.

In conclusion, MALDI-TOF MS protein profiling and DNA barcoding provided similar results in this study, demonstrating that methods of molecular taxonomy provide a viable alternative to often poorly characterized and minuscule morphological characters required for traditional species identification. An integrated approach is especially useful in regions where the sand fly fauna is highly diverse. Because DNA barcoding is much more expensive, time consuming and sequences of many Ethiopian species are not available in online genetic databases, we suggest to develop a centralized MALDI-TOF MS protein profile database and use this approach for routine identification of sand fly specimens from field surveys.

\section{Conclusions}

To the best of our knowledge, this study demonstrates for the first time that MALDI-TOF MS protein profiling is a suitable taxonomical approach for cost-effective, unambiguous species identification of Ethiopian sand flies. DNA- and protein-based molecular techniques as well as morphometric analysis suggest that the vectors of $L$. aethiopica, $P$. pedifer and $P$. longipes, may represent a single species. We also report that the Adlerius species we found, differs from $P$. arabicus, the only Adlerius species reported in Ethiopia to date. This Adlerius species probably represents a new species. Collectively, our results contribute to the understanding of the complex sand fly fauna in Ethiopia, a region heavily burdened with human leishmaniasis.

\section{Supplementary information}

Supplementary information accompanies this paper at https://doi. org/10.1186/s13071-020-04450-2.

Additional file 1: Table S1. Intraspecies K2P distances of cox1 and nad4 genes of Ethiopian sand flies. Abbreviations: K2P, Kimura 2-parameter model; SD, standard deviation.

Additional file 2: Table S2. Interspecies K2P distances of cox 1 and nad4 genes of Ethiopian sand flies. The lower left quadrant presents the K2P distances (SD) of the cox 1 gene, the upper right quadrant of the nad4 gene. The nad4 gene of $P$. duboscai specimens was not included in the analysis ${ }^{a}$. 
Additional file 3: Figure S1. Comparison of MALDI-TOF MS protein profiles of Ethiopian Adlerius sp. with five other species of the subgenus Adlerius. Zoomed mass range of 4 to $15 \mathrm{kDa}$ is depicted.

Additional file 4: Table S3 Interspecies K2P distances of cox1 gene of Phlebotomus sand flies of the subgenus Adlerius.

\section{Abbreviations}

BLAST: Basic Local Alignment Search Tool; cox1: Cytochrome $c$ oxidase subunit 1; CL: Cutaneous leishmaniasis; K2P: Kimura two-parameter model; MALDI-TOF MS: Matrix-assisted laser desorption/ionization time-of-flight mass spectrometry; MCL: Mucocutaneous leishmaniasis; MEGA: Molecular Evolutionary Genetics Analysis; MSP: Main spectrum; NJ: Neighbor joining; SD: Standard deviation; SNNPR: Southern Nations, Nationalities, and Peoples' Region; VL: Visceral leishmaniasis.

\section{Acknowledgements}

We are very grateful to Arba Minch University and Mekelle University and all staff of the regional, zonal and woreda (district) offices for their cooperation and coordination of the field work. Furthermore, we would like to thank Dr Meshesha Belkew for his advice on trapping localities and sand fly identifications

\section{Authors' contributions}

MP, VD and PV designed the study. MP, NG, WD, BM and FM coordinated and carried out the field work. MP, VD, PH and NVH carried out the laboratory analyses. MP, VD, PH and PV analyzed and interpreted the data and wrote the initial manuscript. Resources were arranged by $\mathrm{HL}$, FM and PV. HL, BM, FM, HL and PV participated in the coordination of the project and revised the manuscript. All authors read and approved the final manuscript.

\section{Funding}

$M P$ is a PhD-fellow in the VLADOC program of the Flemish Interuniversity Council VLIR-UOS (NDOC2016PR003) and her research stay at Charles University was supported by an Infravec2 Grant (Agreement No. 731060). HL is part of the University of Antwerp Center of Excellence VAX-IDEA. This research was supported by the projects BIOCEV CZ.1.05/1.1.00/02.0109 from the European Regional Development Fund. Additional support from the Czech Infrastructure for Integrative Structural Biology (LM2015043 funded by MEYS CR) is gratefully acknowledged.

\section{Availability of data and materials}

The datasets analyzed during the present study are available from the corresponding authors on reasonable request.

\section{Ethics approval and consent to participate}

Not applicable.

\section{Consent for publication}

Not applicable.

\section{Competing interests}

The authors declare that they have no competing interests.

\section{Author details}

1 Evolutionary Ecology Group, Biology Department, University of Antwerp, Antwerp, Belgium. ${ }^{2}$ Department of Parasitology, Faculty of Science, Charles University, Prague, Czech Republic. ${ }^{3}$ BioCeV-Institute of Microbiology, The Czech Academy of Sciences, Vestec, Czech Republic. ${ }^{4}$ Biology Department, Arba Minch University, Arba Minch, Ethiopia. ${ }^{5}$ Department of Public Health, Arba Minch University, Arba Minch, Ethiopia.

Received: 15 July 2020 Accepted: 30 October 2020

Published online: 17 November 2020

\section{References}

1. Maroli M, Feliciangeli M, Bichaud L, Charrel R, Gradoni L. Phlebotomine sandflies and the spreading of leishmaniasis and other diseases of public health. Med Vet Entomol. 2013;27:123-47.

2. CDC. Center of Disease Control and Prevention. Parasites - Leishmaniasis. Atlanta: Center of Disease Control and Prevention; 2013. https://www. cdc.gov/parasites/leishmaniasis/biology.html. Accessed 07 Sept 2018.

3. Alvar J, Yactayo S, Bern C. Leishmaniasis and poverty. Trends Parasitol. 2006;22:552-7.

4. Alvar J, Vélez ID, Bern C, Herrero M, Desjeux P, Cano J, et al. Leishmaniasis worldwide and global estimates of its incidence. PLOS ONE. 2012; $7:$ e35671.

5. Lemma W, Tekie H, Abassi I, Balkew M, Gebre-michael T, Warburg A, et al. Nocturnal activities and host preferences of Phlebotomus orientalis in extra-domestic habitats of Kafta-Humera lowlands, Kala-azar endemic, Northwest Ethiopia. Parasit Vectors. 2014;7:594

6. Seblova V, Volfova V, Dvorak V, Pruzinova K, Votypka J, Kassahun A, et al. Phlebotomus orientalis sand flies from two geographically distant Ethiopian localities: biology, genetic analyses and susceptibility to Leishmania donovani. PLoS Negl Trop Dis. 2014;7:e2187.

7. Gebresilassie A, Abbasi I, Aklilu E, Yared S, Kirstein OD, Moncaz A, et al. Host-feeding preference of Phlebotomus orientalis (Diptera: Psychodidae) in an endemic focus of visceral leishmaniasis in northern Ethiopia. Parasit Vectors. 2015:8:270.

8. Gebre-michael T, Malone JB, Balkew M, Ali A, Berhe N, Hailu A, et al. Mapping the potential distribution of Phlebotomus martini and P. orientalis (Diptera: Psychodidae), vectors of kala-azar in East Africa by use of geographic information systems. Acta Trop. 2004;90:73-86.

9. Fuller G, Lemma A, Haile T, Gemeda N. Kala-azar in Ethiopia: survey of south-west Ethiopia. The leishmanin skin test and epidemiological studies. Ann Trop Med Parasitol. 1979:73:417-30.

10. Lemma W, Erenso G, Gadisa E, Balkew M, Gebre-michael T, Hailu A. A zoonotic focus of cutaneous leishmaniasis in Addis Ababa, Ethiopia. Parasit Vectors. 2009;2:60.

11. Pareyn M, Van Den Bosch E, Girma N, Van Houtte N, Van Dongen S, Van Der Auwera G, et al. Ecology and seasonality of sandflies and potential reservoirs of cutaneous leishmaniasis in Ochollo, a hotspot in southern Ethiopia. PLoS Negl Trop Dis. 2019;13:e0007667.

12. Bray RS, Ashford RW, Bray MA. The parasite causing cutaneous leishmaniasis in Ethiopia. Trans R Soc Trop Med Hyg. 1973;67:345-8.

13. van Henten S, Adriaensen W, Fikre H, Akuffo H, Diro E, Hailu A, et al. Cutaneous leishmaniasis due to Leishmania aethiopica. EClinicalMedicine. 2018;65:69-81

14. Hailu A, Di T, Abebe T, Hunegnaw M, Kager PA, Gramiccia M, et al. Isolation of Leishmania tropica from an Ethiopian cutaneous leishmaniasis patient. Trans R Soc Trop Med Hyg. 2006;100:53-8.

15. Bsrat A, Berhe N, Balkew M, Yohannes M, Teklu T, Gadisa E, et al. Epidemiological study of cutaneous leishmaniasis in Saesie Tsaeda-emba district, eastern Tigray, northern Ethiopia. Parasit Vectors. 2015;8:149.

16. Bugssa G, Hailu A, Demtsu B. The current status of cutaneous leishmaniasis and the pattern of lesions in Ochollo primary school students, Ochollo, southwestern Ethiopia. Sci J Clin Med. 2014;3:111-6.

17. Pareyn M, Kochora A, Van Rooy L, Eligo N, Vanden Broecke B, Girma N et al. Feeding behavior and activity of Phlebotomus pedifer and potentia reservoir hosts of Leishmania aethiopica in southwestern Ethiopia. PLoS Negl Trop Dis. 2020;14:e0007947.

18. Galati EAB, Galvis-ovallos F, Lawyer P, Léger N, Depaquit J. An illustrated guide for characters and terminology used in descriptions of Phlebotominae (Diptera, Psychodidae). Parasite. 2017;24:26.

19. Ready PD. Biology of phlebotomine sand flies as vectors of disease agents. Annu Rev Entomol. 2013;58:227-50.

20. Dvorak V, Halada P, Hlavackova K, Dokianakis E, Antoniou M, Volf P. Identification of phlebotomine sand flies (Diptera: Psychodidae) by matrixassisted laser desorption/ionization time of flight mass spectrometry. Parasit Vectors. 2014;7:21.

21. Depaquit J. Molecular systematics applied to Phlebotomine sandflies: review and perspectives. Infect Genet Evol. 2014;28:744-56. 
22. Yssouf A, Almeras L, Raoult D, Parola P. Emerging tools for identification of arthropod vectors. Future Microbiol. 2016;11:549-66.

23. Hoppenheit A, Murugaiyan J, Bauer B, Steuber S. Identification of Tsetse (Glossina spp.) Using matrix-assisted laser desorption/ionisation time of flight mass spectrometry. PLoS Negl Trop Dis. 2013;7:e2305.

24. Kaufmann C, Ziegler D, Schaffner F, Carpenter S, Pfluger V, Mathis A. Evaluation of matrix-assisted laser desorption/ionization time of flight mass spectrometry for characterization of Culicoides nubeculosus biting. Med Vet Entomol. 2011:25:32-8.

25. Müller P, Pflüger V, Wittwer $M$, Ziegler $D$, Chandre F, Simard F, et al. Identification of cryptic Anopheles mosquito species by molecular protein profiling. PLoS ONE. 2013;8:e57486.

26. Lafri I, Almeras L, Bitam I, Caputo A, Yssouf A. Identification of Algerian field-caught phlebotomine sand fly vectors by MALDI-TOF MS. PLOS Negl Trop Dis. 2016;10:e0004351.

27. Mathis A, Depaquit J, Dvorak V, Tuten H, Banuls A, Halada P, et al. Identification of phlebotomine sand flies using one MALDI-TOF MS reference database and two mass spectrometer systems. Parasit Vectors. 2015;8:266

28. Chavy A, Nabet C, Normand AC, Kocher A, Ginouves M, Prévot G, et al. Identification of French Guiana sand flies using MALDI-TOF mass spectrometry with a new mass spectra library. PLoS NegI Trop Dis. 2019;13:e0007031.

29. Arfuso F, Gaglio G, Maria J, Caracappa G, Lupia A, Napoli E, et al. Identification of phlebotomine sand flies through MALDI-TOF mass spectrometry and in-house reference database. Acta Trop. 2019;194:47-52.

30. Lewis DJ, Minter DM, Ashford RW. The subgenus Larroussius of Phlebotomus (Diptera, Psychodidae) in the Ethiopian region. Bull Entomol Res. 1974;64:435-42.

31. Killick-Kendrick R, Tang Y, Killick-Kendrick M, Jhonson RN, Ngumbi P, Sang $D$, et al. Phlebotomine sandflies of Kenya (Diptera: Psychodidae). III. The identification and distribution of species of the subgenus Larroussius. Ann Trop Med Parasitol. 1994;88:183-96.

32. Gebre-Michael T, Lane RP. Distinguishing the females of Phlebotomus (Synphlebotomus) martini and P. (S.) celiae (Diptera: Phlebotominae), vectors of visceral leishmaniasis in southern Ethiopia. Bull Entomol Res. 1993;83:353-60.

33. Rogo LC, Khamala PM, Mutinga MJ. Biochemical identification of Phlebotomus (Larroussius) pedifer and Phlebotomus (Larroussius) elgonensis. Biochem Syst Ecol. 1988;16:655-9.

34. Ashford W, Bray M, Hutchinson P, Bray S. The epidemiology of cutaneous leishmaniasis in Ethiopia. Trans R Soc Trop Med Hyg. 1973;67:4.

35. Gebre-Michael T, Lane RP. The roles of Phlebotomus martini and P. celiae (Diptera: Phlebotominae) as vectors of visceral leishmaniasis in the Aba Roba focus, southern Ethiopia. Med Vet Entomol. 1996;10:53-62.

36. Halada P, Hlavackova K, Risueno J, Berriatua E, Volf P, Dvorak V. Effect of trapping method on species identification of phlebotomine sandflies by MALDI-TOF MS protein. Med Vet Entomol. 2018;32:388-92.

37. Artemiev MM. A revision of sand flies of the subgenus Adlerius (Diptera, Phlebotominae, Phlebotomus). Zool Zhurnal. 1980;59:1177-92.

38. Abonnenc E, Minter DM. Keys for the identification of the sandflies of the Ethiopian region. Cah ORSTOM Entomol Med. 1965;5:25-63.

39. Quate LW. Phlebotomus sand flies of the Paloich area in the Sudan (Diptera: Psychodidae). J Med Entomol. 1964;1:213-68.

40. Lane RP. The sandflies of Egypt (Diptera: Phlebotominae). Bull Br Mus nat Hist. 1986;52:31-5.

41. Lewis DJ, Mutinga MJ, Ashford RW. Phlebotomus longipes Parrot \& Martin (Diptera: Phlebotomidae) and a new related species. J Entomol. 1972:41:119-24.

42. Kirk K, Lewis DJ. Taxonomy of the Ethiopian sandflies (Phlebotomus) II. Keys for the identification of the Ethiopian species. Ann Trop Med Parasitol. 1946:40:117-29.

43. Folmer O, Black M, Hoeh W, Lutz R, Vrijenhoek R. DNA primers for amplification of mitochrondrial cytochrome c oxidase subunit I from diverse metazoan invertebrates. Mol Mar Biol Biotechnol. 1994;3:294-9.
44. Soto SIU, Lehmann T, Rowton ED, Velez ID, Porter CH. Speciation and population structure in the morphospecies Lutzomyia longipalpis (Lutz \& Neiva) as derived from the mitochondrial ND4 gene. Mol Phylogenet Evol. 2001;18:84-93.

45. Thompson JD, Gibson TJ, Plewniak F, Jeanmougin F, Higgins DG The CLUSTAL_X windows interface: flexible strategies for multiple sequence alignment aided by quality analysis tools. Nucleic Acids Res. 1997;25:4876-82.

46. Tamura K, Peterson D, Peterson N, Stecher G, Nei M, Kumar S. MEGA5: Molecular Evolutionary Genetics Analysis using maximum likelihood, evolutionary distance, and maximum parsimony methods research resource. Mol Biol Evol. 2011;28:2731-9.

47. Kimura M. A simple method for estimating evolutionary rates of base substitutions through comparative studies of nucleotide sequences. $J$ Mol Evol. 1980;16:111-20.

48. Nei M, Kumar S. Molecular evolution and phylogenetics. New York: Oxford University Press; 2000. p. 333.

49. Saitou N, Nei M. The neighbor-joining method: a new method for reconstructing phylogenetic trees. Mol Biol Evol. 1987;4:406-25.

50. Lewis DJ, Ledgier JA. African species of Phlebotomus, subgenus Synphlebotomus Theodor (Diptera, Psychodidae), with special reference to South West Africa. Bull Entomol Res. 1976;66:405-12.

51. Killick-Kendrick R, Tang Y, Killick-Kendrick M. Phlebotmine sandflies of Kenya (Diptera: Psychodidae). III. The species of the subgenus Larroussius. Ann Trop Med Parasitol. 1994;88:183-96.

52. Gebresilassie A, Yared S, Aklilu E. Sandfly fauna and ecological analysis of Phlebotomus orientalis and Phlebotomus martini in the lowland foci of visceral leishmaniasis in Somali Regional Stat, southeast Ethiopia. Asian Pac J Trop Med. 2020;13:31-7.

53. Aklilu E, Gebresilassie A, Yared S, Kindu M, Tekie H, Balkew M, et al. Studies on sand fly fauna and ecological analysis of Phlebotomus orientalis in the highland and lowland foci of kala-azar in northwestern Ethiopia. PLoS ONE. 2017;12:e0175308.

54. Davidson I. A morphological study of phlebotomine sandflies and their role in transmission of human leishmaniasis, with a special reference to Namibia. Johannesburg: University of Witwatersand; 1987.

55. Parrot L. Notes sur les phlebotomes XVII Phlebotomes d'Ethiopie. Arch I'Institut paster d'Algerie. 1936;14:30-47.

56. Parrot L, Martin R. Notes sur les phlébotomes XXVIII Ibid. 1939;17:143-56.

57. Absavaran A, Rassi Y, Parvizi P, Oshaghi MA, Rafizadeh S, Mohebali M, et al. Identification of sand flies of the subgenus Larroussius based on molecular and morphological characters in North western Iran. Iran J Arthropod Borne Dis. 2009;3:22-35.

58. Cazan CD, Păstrav IR, lonică AM, Oguz G, Kasap OE, Dvorak V, et al. Updates on the distribution and diversity of sand flies (Diptera: Psychodidae) in Romania. Parasit Vectors. 2019;12:247.

59. Kasap OE, Linton YM, Karakus M, Ozbel Y, Alten B. Revision of the species composition and distribution of Turkish sand flies using DNA barcodes. Parasit Vectors. 2019:12:410

60. Yared S, Gebresilassie A, Akililu E, Deribe K, Balkew M, Warburg A, et al. Diversity and altitudinal distribution of phlebotomine sand flies (Diptera: Psychodidae) in visceral leishmaniasis endemic areas of northwest Ethiopia. Acta Trop. 2017;176:1-10

61. Gebremeskel SY, Balkew M, Warburg A, Hailu A. Nocturnal activity of Phlebotomus species (Diptera: Psychodidae) in a visceral leishmaniasis endemic area of northwest Ethiopia. J Biol Agric Healthc. 2015;5:185-94.

62. Gebre-michael T, Balkew M, Ali A, Ludovisi A, Gramiccia M. The isolation of Leishmania tropica and L. aethiopica from Phlebotomus (Paraphlebotomus) species (Diptera: Psychodidae) in the Awash Valley, northeastern Ethiopia. Trans R Soc Trop Med Hyg. 2004;98:64-70.

63. Svobodova M, Votypka J, Peckova J, Dvorak V, Nasereddin A, Baneth G, et al. Distinct transmission cycles of Leishmania tropica in 2 adjacent foci, northern Israel. Emerg Infect Dis. 2006;12:1860-8. 
64. Lewis D, Buttiker W. Insects of Saudi Arabia: the taxonomy and distribution of Saudi Arabian Phlebotomus sandflies (Diptera: Psychodidae). Fauna Saudi Arab. 1982;4:353-97.

65. Lewis D, Büttiker W. Some Phlebotomine sandflies (Diptera: Psychodidae) from Saudi Arabia. Fauna Saudi Arab. 1986;8:324-39.

66. OpenAFRICA: Ethiopia shapefiles. 2016. https://africaopendata.org/datas et/ethiopia-shapefiles. Accessed 8 Aug 2018
67. QGIS Development team. QGIS Geographic Information System. Open Source Geospatial Foundation Project; 2019. https://qgis.osgeo.org.

\section{Publisher's Note}

Springer Nature remains neutral with regard to jurisdictional claims in published maps and institutional affiliations.
Ready to submit your research? Choose BMC and benefit from:

- fast, convenient online submission

- thorough peer review by experienced researchers in your field

- rapid publication on acceptance

- support for research data, including large and complex data types

- gold Open Access which fosters wider collaboration and increased citations

- maximum visibility for your research: over $100 \mathrm{M}$ website views per year

At BMC, research is always in progress.

Learn more biomedcentral.com/submissions 